\title{
Sustenance of Tourism Industry for the Socio-economic Development of Ekiti State, Nigeria
}

\author{
Olayemi O. Simon-oke ${ }^{1,2} \&$ Amen O. Jegede $e^{1,2}$ \\ ${ }^{1}$ Departments of Project Management Technology, Federal University of Technology, Akure, Ondo State, \\ Nigeria \\ ${ }^{2}$ Department of Geography \& Planning Science, Ekiti State University, Ado-Ekiti, Nigeria \\ Correspondence: Amen O. Jegede, Department of Geography and Planning Science, Ekiti State University, \\ Ado-Ekiti, Nigeria. Tel: 234-803-408-5063. E-mail: honourablejegede@yahoo.com
}

Received: December 7, $2011 \quad$ Accepted: May 21, $2012 \quad$ Online Published: August 3, 2012

doi:10.5539/jedp.v2n2p51 URL: http://dx.doi.org/10.5539/jedp.v2n2p51

\begin{abstract}
This study examined the sustenance of tourism sector for the socio-economic development of Ekiti State, Nigeria. Tourism is playing an increasingly important role in the economy of many nations in the world today, especially in the area of job creation. Data for this study were collected from primary sources through the administration of two (2) sets of a well structured interview questionnaire. One hundred and fifty (150) were administered on workers/management of the randomly selected (50 each) in the study area. Another 150 questionnaires (50 each) were also randomly administered on visitors/patronizers of the hotels in the study area. Results from this study showed that management practices as well as management information system (MIS) in most of the hotels from the study area varies and not encouraging. This study therefore recommends that modern management practices and information system should be a priority in the study area. This study will be useful to government, planners, researchers, investors, policy makers and individuals in ensuring the sustenance of tourism for the socio-economic development of Ekiti State, Nigeria.
\end{abstract}

Keywords: development, Ekiti State, Nigeria, socio-economic, sustenance, tourism industry

\section{Introduction}

Tourism is known to create jobs at various levels that are essential to the growth of the rural and national economy of a country (Ekechukwu, 2010).

The world Tourism organization (WTO) at an International Government Conference held in Ottawa, Canada in 1991, defined Tourism as comprising the activities of persons travelling to and staying in places outside their usual environment for not more than one consecutive year for leisure, business or other purposes (Holloway, 2006). That tourism is a thriving industry worldwide is a well established fact. As an industry, it is either the backbone or one of the top three fastest growing industries in countries like Kenya, U.S.A., Indonesia, Canada, France, United Kingdom, the Bahamas and Barbados etc. As far as Nigeria is concerned, tourism attraction centres is still very young, and there is paucity of data on its growth pattern (Afolabi, 2008).

Nigeria's effort directed at developing the tourism industry can be dated back to 1900, when Lokoja was the seat of Lord Lugard, the Governor General of Nigeria, in Colonial history, Lokoja was therefore the capital of Nigeria between 1900 and 1901. Realizing these potentials, scholars commenced development research works to generate ideas and data on which policies on tourism development could be based (Obateru, 2004).

In January 2001, the National Tourism Development Commission (NTDS) Abuja commenced the registration of tourism enterprises in order to harmonize all efforts directed at developing the tourist facilities in Nigeria. Ekiti State benefited a great deal from the exercise, in that it made possible, inventory and capacity building in the tourism industry (Obateru, 2004).

Tourism is now one of the world's largest industries and one of its fastest growing economic sectors (Grace \& Querini, 2011). They further noted that for many countries, tourism is seen as a main instrument for regional development, as it stimulates new economic activities.

Tourism is playing an increasingly important role in the economy of many nations in the world today, 
contributing to their economic growth and job creation, and providing employment and income (Allan, 2002). Because tourism industry is seen as growth sectors and continue to be considered as labour intensive with low entry possibilities, policy makers tend to view the development of tourism as a way to tackle unemployment and underemployment. This is especially the case for persons at the bottom of the labour market, such as unemployed youth, the long-term unemployed, the less-skilled, ethnic minority groups and, to some degree, women (re-entering the labour market) (Michael, 2010).

Tourism is about people. Visitors are people, subject to changes in their behavior, demands and decision making. Changes are difficult to predict and anticipate. Tourism products and services are also about people (Allan, 2002). Tourism is travel for recreational, leisure or business purposes. The World Tourism Organization (2009) defines tourists as people who travel to and stay in places outside their usual environment for more than twenty-four (24) hours and not more than one consecutive year for leisure, business and other purposes not related to the exercise of an activity remunerated from within the place visited (World Tourism Organization, 2009).

Tourism has high levels of disposable income, considerable leisure time is well educated and have sophisticated tastes (Michael, 2010). Michael, (2010). Further stated that there is now a demand for a better quality products, which has resulted in the fragmentation of the mass markets for beach vacations; people want more specialized versions, quieter resorts, family-oriented holidays or niche market target destination hotels.

Sustainable tourism is envisaged as leading to management of all resources in such a way that economic, social and aesthetic needs can be fulfilled, while maintaining cultural integrity, essential ecological process, biological diversity and life support systems (World Tourism Organization, 2009). Sustainable tourism can be seen as having regard to ecological and socio-cultural arming capacities and includes involving the community of the destination in tourism development planning (World Tourism Organization, 2010). It also involves integrating tourism to match current economic and growth policies, so as to mitigate some of the negative economic and social impact of mass tourism.

However, Butler (2006) questioned the exposition of the term "sustainable" in the context of tourism, citing its ambiguity and stating that "emerging sustainable/development philosophy of the 1990's can be viewed as an extension of the broader realization that a preoccupation with economic growth without regard to it social and environmental consequences are self defeating in the long-term". Thus, "sustainable tourism development" is seldom considered as an autonomous function of economic regeneration or as separated from general economic growth. In-view of the background information and various conceptional definitions on the subject matter of tourism, the study generally is to investigate how tourism could be sustained for socio-economic development in Ekiti State, Nigeria; and specifically to;

i) Examine the fact that tourist facilities and investment or spending of visitors, which is a reflection of regional income, co-vary.

ii) Examine the rate of patronage of hotels in their socio-economic contribution to the development of Ekiti State.

For the purpose of this study, the following working hypotheses have been developed in line with the stated objectives of the study.

i) There is no significant relationship between tourist facilities " $\mathrm{X}$ " and tourists' investment or spending of regional income.

ii) There is no significant difference in the rate of patronage of hotels and their socio-economic contribution to the development of Ekiti State.

\subsection{The Study Area}

Ekiti State is located between latitude $7^{\circ} 30^{1}$ and $8^{\circ} 15^{1}$ north of the equator and longitude $4^{\circ} 47^{1}$ and $5^{\circ} 40^{1}$ of the Greenwich meridian. Ekiti State was created on the 1st of October, 1996 and the naming of Ado-Ekiti as her administrative headquarter has witnessed rapid population growth and urbanization in the city. The estimated population figure of Ekiti State released by the National Population Commission (NPC) stood at 2,353,082 (NPC, 2006).

The relief of Ekiti State consists of undulating plains. The highest contour line of $540 \mathrm{~m}$ above sea level is found around the north eastern limit of the state. The rocks are dominated by the crystalline rocks, which form parts of the basement complex geology of the South-west Nigeria. The development of Ekiti State spread towards the routes of communication put differently, the settlement evolution, structure and growth is a replica of Homer Hoyt's Sector theory of 1939, which posits the sprawl of physical development in the direction of transportation routes. 
Ekiti State has a total annual rainfall of about $1400 \mathrm{~mm}$ with a low co-efficient variation of about $30 \%$ during the rainfall peak months, and with an average of about 112 rainy days per anon (Adebayo, 1993).

\subsection{Conceptual Framework / Literature Review}

The concept of sustainable development is applied to this study. The concept of sustainable development was pronounced by the World Commission on Environment and Development (WCED) in 1987. This concept noted that sustainable development is a development that meets the needs of the present generation without compromising the ability of future generation to meet their own needs. Development involves the purposeful change of the inherently complex environmental systems. The natural resources system (Ecosystem resources, archeological gardens, historical sites, Ikogosi warm spring etc) and man-made resources (Hotel facilities) are commonly utilized and multi-purpose in their social and economic roles, consequently, the effects of bad management are often wide spread both geographically and economically (Birch, 2007). From the foregoing, it is crystal clear, that ecosystem resources, environmental factors, human needs and hotel facilities are independent. A system analysis or assessment of the total economy and hotel facilities, archeological gardens, and historical sites should be part of the overall planning process. In making developmental decisions, efforts to maintain or improve environmental quality, sustainable tourism resources and improved patronage of tourism centres should be given sufficient weight. This is the basis of the concept of sustainable development, an idea first proposed in the eighties by the World Commission on Environment and Development (Rilwani and Osayande, 2003).

In essence, Sustainable Development is a process of change in which the exploitation of tourism resources, the direction of tourism patronage and investment, the orientation of basic socio amenities and institutional change are all in harmony and enhances both the present and future potentials of tourism facilities and centres to meet human needs and aspiration (World Commission on Environment and Development, 1987).

On the review of literatures, Agardy (2008) observed that the demand for tourism centres does not only depend on the prices and supply of nature-based tourism, but on the class of people, who are the ecotourism experiences are increasing to meet the diversity of demands. Some people want to learn about wildlife or indigenous people. Others are adventure driven tourists, people who want to climb a mountain, or raft down white water rapids.

Munn (2003) stated that tourism attraction centres can provide a strong economic rationale to preserve areas rather than converting them to alternative activities, such as crop or pasture land, adding that economic valuation is increasing being used to demonstrate the value of wild lives and demands, given what tourists are willing to pay to see them. As economic valuation methods improve, and are increasingly used to reflect the costs and benefits of alternative forms of land use, it is likely that tourism will provide one important component of the benefits provided that reasonable revenue is collected at these sites.

Haroun and Boo (2005) opined that acceptable and sustainable level of tourism centres will depend on the biological features of the zone, the fragility of the species and ecosystems in the park and the current and future disturbances and threats, as well as the human and economic resources available to run the park and provide services and facilities for tourists.

Savage (2009) stated that facilities and services that need to be present in a park for tourist centres depend on the zoning, combined with an analysis of the type of tourists' the park wants to attract, the proximity of alternates facilities, acceptable levels of impact and the revenue the park wants to generate. He further stressed that a combination of factors may make it preferable to locate most services, especially accommodation outside, rather than inside parks. Thus, different types of ecotourism (e.g., hard or soft) require different facilities.

Sowers (2001) posited that educating tourists about the functions of tourism centres and facilities and how best other tourism attraction centres can best be utilized, what it connotes, why it exists, what the restrictions are, its boundaries, and the ecological services are key elements of tourism enlightenment plan. There are three groups which should be considered when developing such a plan: international visitors, national residents, and local residents, including children, strong informative programmes, describing tourism regulations and acceptable behavior, coupled with enhanced guide and good services, are key elements of tourism development centres. The impact of visitors should be restricted by limiting them to certain railways, roads or boats.

\section{Methodology}

\subsection{Research Design}

The research design for this study is based on the careful gathering, analysis and application of facts in order to achieve the stated objectives and to enlist the acceptability or otherwise of the objectives and hypotheses state in this study. 
Data for this study were collected from primary sources. The primary sources of data collected were generated through the use of questionnaires that were used by the researcher and upon such information further analysis were done. This study therefore employed the primary source of data collection with the random administration of three hundred (300) structured questionnaires on respondents within the randomly selected local Government in the 3 senatorial districts in Ekiti State, to ascertain the needed data for the study.

\subsection{Strategy for Questionnaire Administration}

Ekiti State, which is the study area, harbours three (3) senatorial districts and sixteen (16) Local Government Areas. In Ekiti Central Senatorial District: Ado Local Government Area was randomly selected from Ekiti South Senatorial Districts Ikere Local Government Area was randomly selected, and in Ekiti North Senatorial District: Ikole Local Government Area was equally selected.

The questionnaire designed for this study were administered on respondents from the three Local Government Areas, which were selected with the aid of multi-stage random sampling, one each from the three (3) Senatorial Districts in Ekiti State.

They are:

i) Ado Local Government Area in Ekiti Central Senatorial District

ii) Ikole Local Government Area in Ekiti North Senatorial District and,

iii) Ikere Local Government Area in Ekiti South Senatorial District.

Thereafter, one hotel each was randomly selected from the three (3) Local Government Areas, they are:

i. Pathfinder Hotel in Ado Local Government Area of Ekiti Central Senatorial District

ii. Ifelodun Hotel in Ikole Local Government Area of Ekiti North Senatorial District and

iii. Korode Hotel in Ikere Local Government Area of Ekiti South Senatorial District.

Thus, two sets of well structured interview questionnaires were randomly administered in this research work. To this extent, fifty (50) questionnaire each were randomly administered on the workers and management of the three randomly selected tourism centre /hotels of a total of one hundred and fifty (15) questionnaires in the study area. Another one hundred and fifty (150) questionnaires were also randomly administered on visitors/patronizers of the same randomly selected tourism centres/hotels in the study area.

\section{Results and Discussions}

\subsection{Presentation of Results and Testing of Hypotheses}

Hypothesis 1

There is no significant relationship between tourist facilities " $\mathrm{X}$ " and tourist investment or spending of regional income of Ekiti State "Y".

Table 1. Testing of hypothesis 1, data on statistical measures of both "X" and "Y" variables

\begin{tabular}{|c|c|c|c|c|c|}
\hline Paired groups & Mean & Standard deviation & Degree freedom & "tt" cal & "tt" tab \\
\hline $\begin{array}{l}\text { "X" Tourist } \\
\text { facilities }\end{array}$ & & & & & \\
\hline $\begin{array}{l}\text { "Y" Tourist } \\
\text { investment }\end{array}$ & -19.0950 & 2.94266 & 199 & 91.769 & 1.960 \\
\hline
\end{tabular}

Authors Field Survey, 2011.

In table 1, the "t" calculated value (91.769) is greater than the " $\mathrm{t}$ " table value (1.960), we therefore reject the null hypothesis in favour of the alternative hypothesis, by stating that as tourist centres increases, patronage of tourist destinations increase and hence the tourist investment and economic potency increases and sources of income generated in Ekiti State.

Hypothesis 2

There is no significant difference in the number of tourists induced to tourism centres in Ekiti State. 
Table 2. Number of tourists received by tourism centres

\begin{tabular}{lll}
\hline Hotel A & Hotel B & Hotel C \\
\hline Pathfinder Hotel & Ifelodun Hotel & Korode Hotel \\
120 & 100 & 80 \\
\hline
\end{tabular}

Authors Field Survey, 2011.

Test of significance in this case, there are three tourism centres.

The degree of freedom is 3-1=2. A significance level of 0.05 is applied. The table value of the sum of square is 9.21, whereas, the calculated sum of square is 23.5 . The latter indicates a larger value of chi-square and since it is comparatively larger than the table value of the chi-square, the null hypothesis (Ho) was rejected in favour of the alternative hypothesis. This suggests that, there is a significant difference between the observed and the expected frequencies and this implies that the three selected tourism centers, hotels; parks/mecums receives significance different numbers of visitors or tourists.

\subsection{Discussion of Findings}

Factors that accounts for the differences in the number of tourism the hotels/park/museum patronage in the study area.

i) The management practices adopted by each of the tourism centres; hotel/parks/museum varies from one place to another.

ii) The surroundings/environment of Pathfinder Hotel was the most beautiful out of the three tourism centres, hotel, parks/museum in the study area. Tourists can easily relax there in.

iii) In both Pathfinder Hotel and Ifelodun Hotel, there were possibilities of support for members of staff, for further training than in Korode Hotel.

iv) Modern tourist facilities that attracts tourist were more available in Pathfinder Hotel and Ifelodun Hotel, than at Korode Hotel.

v) Hotel issues and environmental problems were better monitored and discussed more in Hotel C.

vi) Members of the management team were disciplined in both Pathfinder Hotel and Korode Hotel than Ifelodun Hotels. The Junior Staff were observed to be highly disciplined, also constantly review in Pathfinder Hotel, than in the other hotel.

vii) It was equally discovered, that Management Information System (MIS) in the three hotels was poor, and there is need for improvement of the technology and information gadgets in other to provide the right kind of information for decision making, and this should cover both data on tourist, yearning and recreational activities.

\section{Recommendations}

The predominance of tourism attraction centres in Ekiti State is yearning for a prompt and well a articulated policy and dynamic zeal to harness them, while those that haphazardly and cursorily developed deserve enthusiastic revitalization.

There is need to initiate a policy mandating the Hotels in the study area and Tourism Board to organize frequently, jamborees during festive period for inhabitants within the study area.

Moreover, apart from making adequate publicity for such occasions, public consumption/patronage should be strengthened through subsidized transport facilities to tourism attraction centres in the study area.

The State Tourism Board should take responsible steps at enlightening the populace on the available tourism resources in the study area on how best; it can be visited with maximum pleasure.

The state government should revitalize tourism campaign, utilizing the state radio and television in the diverse dialects in the state to boost tourism patronage and encourage indigenes and foreigners to tourism centres in the study area.

There is need for sustainable development of tourism centres, preservation and conservation of fauna and flora resources in the study area.

There is need to ensure a clean environment by government, Environmental Sanitation Officers and individuals, so also to motivate investors to invest in the tourism sector in the state. 


\section{Conclusion}

Tourism sector in Ekiti State is based primarily on its natural resources, cultural heritage and anthropogenic resources in form of hotels, museums and parks. The government at all levels in the state should make the sustenance of tourism industry a priority and also ensure that opportunities are available for tourists to gain, enjoy and have satisfying experience in available tourist centres in the study area.

\section{References}

Afolabi, F. I. (2008). Women Recreation Centres in Ado-Ekiti, Nigeria (pp.1-4a). Hope Paper Mills, Nigeria Limited, Ado-Ekiti.

Agardy, M. T. (2008). Accommodating Ecotourism in Multiple use planning of Coastal and Marine Protected Areas. Ocean and Coastal Management, 20, 219-239. http://dx.doi.org/10.1016/0964-5691(93)90068-A

Allan, B. (2002). A Dictionary of Travel and Tourism Terminology. Wallingford CAB International Publications.

Birch, J. W. (2007). Geographical Resources Management. Nebular, John Willey Publications.

Chokot, B. A. (1993). Environment and Tourism in Nigeria (pp. 1-34). Environment and Behaviour Association of Nigeria (EBAN) University of Lagos, Nigeria.

Creace, S., \& Querini, G. (2011). The Role of Tourism in Sustainable Economic Development. Jena Economic Research Paper, 113(3), 481-492.

Ekechukwu, L. C. (2010). Pathways for Harnessing. The Tourism potential of Natural and cultural sites and features on the Nsukka Okigwe Cuesta. International Journal of Research in Arts and Social Sciences, 2, $1-11$.

Haroun R., \& Boo, D. (2005). The concert of ecotourism Policy and planning. In Fennell, D. A., \& R. K. Dawling (eds.), Ecotourism Policy and Planning (pp. 1-22). Oxon. CABI Publishing .

Holloway, J. C. (2006). Pathways for Harnessing. The Tourism potential of Natural and cultural sites and features on the Nsukka Okigwe Cuesta. International Journal of Research in Arts and Social Sciences, 2, $1-11$.

Michael, Q. (2010). Dark Tourism Washington, D.C. World Wide Words Publication.

Munn, J. F. (2003). Tourism: “The World Peace Industry”. Recreation Canada, 48(1), 24-33.

National Population Commission. (2007). Retrieved from www.onlinenigeria.com.

Obateru, I. O. (2004). Outdoor Recreation Behaviour of Ibadan Residents. A Geographical Analysis. Ibadan, University of Ibadan, Nigeria.

Olatunji, A. J. (2006). On the introduction to Theoretical Geography. Akure, BJ Production.

Rilwani, H., \& Osayande, A. O. (2003). Rural Planning and National Development Strategy. Benin City, Vinco Publishers.

Savage, T. Y. (2009). Global Bio Diversity States of the Earth's Living Resources. London, Chapman and Hall.

Sowers, M. (2001). The Silent Jungle Ecotourism among the Kuna Indian in Panama. Cultural Survival Quarterly, 14(1), 42-45.

World Tourism Organization (2009). Collection of Tourism Expenditure Statistics. World Tourism Organization Publications. 